\title{
Expression and localization of COX-2 in human airways and cultured airway epithelial cells
}

\author{
D.N. Watkins*+, D.J. Peroni*, J.C. Lenzo*, D.A. Knight*, M.J. Garlepp*\#, P.J. Thompson*
}

Expression and localization of COX-2 in human airways and cultured airway epithelial cells. D.N. Watkins, D.J. Peroni, J.C. Lenzo, D.A. Knight, M.J. Garlepp, P.J. Thompson. (C) ERS Journals Ltd 1999.

ABSTRACT: Cyclo-oxygenase is the rate-limiting enzyme in the prostanoid pathway. Although expression of the inducible isoform of cyclo-oxygenase (COX-2) is associated with cytokine-mediated inflammation, recent evidence suggests a homeostatic role for epithelial COX-2 in the gastrointestinal tract. The aim of this study was to examine the expression and localization of COX-2 in human airway epithelium both in vivo and in vitro.

Human airway specimens from patients undergoing lung resection surgery for primary lung tumours $(n=10)$ or nasal mucosal resection for non-inflammatory nasal obstruction $(\mathrm{n}=5)$ were examined for $\mathrm{COX}-2$ expression by in situ hybridization and immunohistochemistry. COX-2 expression was also studied in two human airway epithelial cell lines (BEAS-2B and A549) using reverse transcription polymerase chain reaction and Northern and Western blot analysis.

COX-2 messenger ribonucleic acid (mRNA) and protein were localized to individual columnar epithelial cells and to airway resident inflammatory cells in $9 / 10$ lower and 5/5 upper airway specimens. Expression of COX-2 did not correlate with evidence of airway inflammation. Focal expression of COX-2 mRNA and protein was observed in bronchus-associated lymphoid tissue. Both COX-2 mRNA and protein were detected in BEAS-2B and A549 cells cultured under standard conditions.

In conclusion, expression of COX-2 in human airway epithelium occurs in the upper and lower airways, is widespread in airway epithelial and airway resident inflam-matory cells in the absence of overt airway inflammation, and is detectable in cultured human airway epithelial cells in the absence of inflammatory cytokine stimulation. These data suggest a potentially important homeostatic role for COX-2 in the regu-lation of human airway contractility, inflammation and immune responses. Eur Respir J 1999; 13: 999-1007.

Prostaglandins are lipid mediators of central importance in the regulation of inflammation and smooth muscle tone [1]. Airway-resident inflammatory cells release prostaglandins $(\mathrm{PG}) \mathrm{D}_{2}$ and $\mathrm{PDF}_{2 \alpha}$ which amplify smooth muscle contraction and airway inflammation [1]. In contrast, the predominant product of mammalian airway epithelium, $\mathrm{PGE}_{2}$, is thought to play a role in the downregulation of allergic inflammation [2] and modulates histamine-induced bronchoconstrictor responses in human airways [3]. In addition, studies in animal airways [2], ex vivo epithelial cultures [1] and cultured human airway epithelial cells [4] have demonstrated epithelial $\mathrm{PGE}_{2}$ production both de novo and in response to inflammatory cytokine stimulation.

Following its conversion from membrane phospholipids by phospholipase, arachidonic acid enters the prostanoid pathway via cyclo-oxygenase (COX), which catalyses the conversion of arachidonic acid to $\mathrm{PGH}_{2}$ [5]. $\mathrm{PGH}_{2}$ is then converted to biologically active prostaglandins by cellspecific prostaglandin synthases [6]. As COX is the rate limiting step in the prostaglandin pathway, the regulation of this enzyme is of critical importance in prostaglandin production [6].
*Asthma and Allergy Research Unit, University Dept of Medicine, Queen Elizabeth II Medical Centre, Nedlands, Western Australia. ${ }^{+}$Tumor Biology, Johns Hopkins Oncology Center, Baltimore, MD, USA. "Dept of Pharmacy, Curtin University, Perth, Western Australia.

Correspondence: P.J. Thompson, Asthma and Allergy Research Unit, University Dept of Medicine, Queen Elizabeth II Medical Centre, Nedlands 6009, Western Australia, Fax: 61893462816

\section{Keywords: Airway epithelium} immunohistochemistry inducible cyclo-oxygenase inflammatory cells in situ hybridization prostaglandins

\section{Received: May 281998}

Accepted after revision January 261999

This research was supported by the National Health and Medical Research Council, the Sir Charles Gairdner Hospital Research Foundation and the Garnett Passe Rodney Williams Memorial Foundation.
The constitutive isoform of $\mathrm{COX}(\mathrm{COX}-1)$ subserves a homeostatic role [6]. The inducible isoform (COX-2), normally absent from cells, is transcriptionally upregulated by pro-inflammatory cytokines and growth factors $[6,7]$. Expression of COX-2 messenger ribonucleic acid (mR$\mathrm{NA}$ ) in response to inflammatory cytokines has been well documented [7], and in vitro studies have demonstrated expression and activity of COX-2 in response to cytokine stimulation in human airway epithelium $[4,8]$ and smooth muscle [9]. Furthermore, it has been shown that endogenous nitric oxide is an important regulator of COX-2 activity in the human airway epithelium in vitro [4], although the significance of these findings for the intact human airway is yet to be established. In addition, the coexpression of COX-2 mRNA and protein has not been studied in human airways. nor have localization studies for COX-2 in airway smooth muscle of human airways been performed.

Although COX-2 expression is characteristically associated with cytokine-mediated inflammation, recent studies have suggested an important homeostatic role for this enzyme. The findings of severe renal pathology in the COX2 knockout mouse [10] and enhanced colonic mucosal 
injury associated with COX-2 inhibition in the rat [11], and the demonstration of "constitutive" COX-2 expression in the epithelium of the rat stomach [12] suggest that COX-2 expression may not be restricted to the production of prostanoids in association with inflammation or tissue injury.

It was hypothesized that human airway epithelial cells constitutively express COX-2 mRNA and protein both in vivo and in vitro. The aim of this study was to examine the expression and localization of COX-2 mRNA and protein in upper and lower human airway specimens obtained surgically from subjects without overt airway inflammation. In order to validate the identity of COX-2 mRNA and protein, and to examine the pathways of COX-2 regulation in human airway epithelium, COX-2 expression was studied in cultured human airway epithelium by both Northern and Western blot analysis.

\section{Materials and methods}

\section{Source of materials}

Unless otherwise stated, all chemicals were obtained from Sigma (Sydney, Australia).

\section{Tissue preparation}

Medium-sized lower airway specimens $(n=10)$ from patients undergoing lobectomy or pneumonectomy for lung tumours, and nasal turbinate specimens $(n=5)$ from patients undergoing surgery for deviated nasal septum were processed immediately following resection by fixation in $4 \%$ paraformaldehyde (BDH, Perth, Australia) at $4{ }^{\circ} \mathrm{C}$ for $8 \mathrm{~h}$ prior to mounting in paraffin blocks. Prior to sectioning for localization studies, each specimen was sectioned and stained with haematoxylin and eosin for pathological examination.

\section{Cell culture}

A simian virus (SV) 40-immortalized human bronchial epithelial (BEAS-2B) cell line, was obtained from the American Type Culture Collection (ATCC; Rockville, MD, USA) and grown according to established methods $[13,14]$. A human airway epithelial carcinoma cell line (A549) [15] was also obtained from the ATCC and cultured according to standard protocols [4].

\section{Reverse transcription-polymerase chain reaction}

Extraction and reverse transcription of total cellular RNA was performed according to standard protocols [14]. To amplify COX-2 complementary deoxyribonucleic acid (cDNA), specific intron-spanning 20-mer primers were designed based on published cDNA sequences obtained from Genbank (http://www.ncbi.nlm.nih.gov/Web/Se$\mathrm{arch} /$ index.html). The oligonucleotides used are shown in table 1 . In order to detect significant fluctuations in the efficiency of reverse transcription (RT) and polymerase chain reaction (PCR) amplification, primers for $\beta$-actin, a ubiquitous housekeeping gene, were added to each reaction to act as an internal control. PCR amplification was performed according to established methods [14]. Reaction conditions were as follows: $94^{\circ} \mathrm{C}$ for $5 \mathrm{~min}, 55^{\circ} \mathrm{C}$ for $1 \mathrm{~min}, 72^{\circ} \mathrm{C}$ for $2 \mathrm{~min}$ for 1 cycle, followed by $94^{\circ} \mathrm{C}$ for $30 \mathrm{~s}, 55^{\circ} \mathrm{C}$ for $1 \mathrm{~min}, 72^{\circ} \mathrm{C}$ for 2 min for 35 cycles. Positive controls consisted of $1 \mathrm{ng}$ of a plasmid construct containing the full COX-2 cDNA kindly donated by T. Hla (Dept of Molecular Biology, Holland Laboratory, American Red Cross, Rockville, USA). Negative controls consisted of RT reaction mixtures without avian myeloblastosis virus (AMV)RT. Southern blot analysis of PCR products was performed as described [14]. A plasmid containing the COX-2 cDNA referred to above served as a template for probe synthesis.

\section{Northern blot analysis of total ribonucleic acid}

Heat-denatured samples of total cellular RNA (20 $\mu \mathrm{g})$ extracted from cell cultures were electrophoresed on a $1 \%$ agarose $/ 1.5 \%$ formaldehyde gel prior to transfer to a Hybond $\mathrm{N}+$ (Amersham Pharmacia Biotech, Castle Hill, NSW, Australia) membrane. The linearized plasmid construct described above served as a template for the synthesis of a ${ }^{32}$ P-ribouridine triphosphate (rUTP) antisense RNA probe using a Gemini ${ }^{\mathrm{TM}}$ in vitro transcription system (Promega, Madison, WI, USA). Hybridization was performed in $5 \times$ saline sodium phosphate, ethylenediaminetetraacetic acid $(\mathrm{SSPE}) / 5 \times$ Denhardt's solution $/ 0.5 \%$ sodium dodecylsulphate (SDS)/heat-denatured herring sperm DNA $20 \mu \mathrm{g} \cdot \mathrm{mL}^{-1} / 50 \%$ formamide at $55^{\circ} \mathrm{C}$. Membranes were then washed at $75^{\circ} \mathrm{C}$ in $2 \times$ saline, sodium citrate (SSC)/ $0.1 \%$ SDS and $0.1 \times \mathrm{SSC} / 0.1 \%$ SDS for $20 \mathrm{~min}$ each and exposed to film for $48 \mathrm{~h}$.

\section{In Situ hybridization}

Localization of COX-2 mRNA was performed by in situ hybridization as described previously [14]. Sections were hybridized with a COX-2-specific ${ }^{35}$ S-rUTP-labelled antisense riboprobe, or a complementary sense probe as a negative control. Autoradiography was performed by coating the slides in Kodak NTB2 (Kodak, Melbourne, Australia) emulsion and exposing for 7-28 days. Slides were then developed and counterstained with haematoxylin.

\section{Immunohistochemistry}

Immunolocalization of the COX-2 protein was performed using a modification of the method of ISEKI [12], as described [14]. Sections were incubated with a rabbit polyclonal anti-COX-2 antibody (Cayman Chemical Co. Ann Arbor, MI, USA). This antibody has previously been shown to be monospecific for COX-2 in paraffin-fixed tissues [12]. Control slides consisted of sections incubated with antibody preadsorbed with an equimolar concentration of purified COX-2 protein (Cayman Chemical Co.), as described [12]. Following washing and incubation with a biotinylated anti-mouse immunoglobulin (Ig)G secondary antibody (DAKO Corporation, Botany, NSW, Australia) and with streptavidin-horseradish peroxidase (DAKO), sections were treated with diaminobenzidine and counterstained with haematoxylin. 
Table 1. - Oligonucleotide primers used for polymerase chain reaction amplification

\begin{tabular}{|c|c|c|}
\hline Target & Primers & Product (bp) \\
\hline $\mathrm{COX}-2$ & 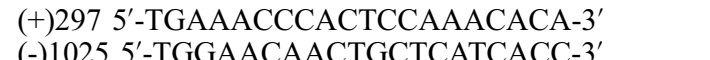 & 728 \\
\hline$\beta$-actin & $\begin{array}{l}\text { (+)1267 5'-CGTGACATTAAGGAGAAGCTGTGC-3' } \\
(-) 1618 \text { 5'-CTCAGGAGGAGCAATGATCTTGAT-3' }\end{array}$ & 375 \\
\hline
\end{tabular}

bp: base pair.

Semi-quantitative analysis of in situ hybridization and immunohistochemistry sections

Semi-quantitative scoring of in situ hybridization and immunohistochemical signals was performed using the method described by DeTRE et al. [16] by two investigators (D.N.Watkins and J.C. Lenzo). The product of the percentage positive cell score (1-6) and the average signal intensity per cell ( $0-3)$ was recorded in six $40 \times$ fields in each section. The score for each specimen was then recorded as the average of the six areas examined.

\section{Immunoblotting}

Cells were lysed in sample buffer $(0.067$ M Tris; $13 \%$ glycerol; $50 \mathrm{mM}$ dithiothreitol; 1.3\% (w/v) SDS; 0.0025\% bromphenol blue; $2 \%$ 2-mercaptoethanol), boiled for 10 min and electrophoresed on a $10 \%$ reducing polyacrylamide gel. Protein was then transferred to nitrocellulose membranes (BioRad, North Ryde, Australia). Following blocking with 3\% BLOTTO (BioRad) in Tween/Trisbuffered saline (TTBS) (20 mM Tris- $\mathrm{HCl} \mathrm{pH} \mathrm{7.5;} 500 \mathrm{mM}$ $\mathrm{NaCl}$ and $0.1 \%$ Tween-20), membranes were incubated with the anti-COX-2 polyclonal antibody described above (Cayman), diluted 1:1,000 in TTBS, for $2 \mathrm{~h}$ at room temperature. Membranes were washed twice in TTBS, then twice in $50 \mathrm{mM}$ Tris $\mathrm{pH} 7.5 ; 500 \mathrm{mM} \mathrm{NaCl}$, and finally reequilibrated in TTBS. Membranes were then incubated with biotinylated goat anti-rabbit immunoglobulin (Sigma) at a dilution of 1:4,000 in TTBS for $1 \mathrm{~h}$ at room tem- perature. Immunoblot detection was then performed using enhanced chemiluminescence according to standard protocols. Purified COX-2 protein (Cayman) was used as a positive control.

\section{Results}

\section{Patient data}

Tissue specimens were obtained from patients undergoing resection of lung tumours $(\mathrm{n}=10)$ and for deviated nasal septum $(\mathrm{n}=5)$. Relevant patient characteristics are summarized in tables 2 and 3.

Pathological examination of haematoxylin and eosinstained specimens

Morphological features in the lower airways demonstrated minor basement membrane thickening (6/10) without evidence of epithelial shedding or metaplastic changes in the epithelial layer. Compared to the specimen obtained from patient 2 (a lifelong nonsmoker), some of the remaining specimens demonstrated increased numbers of mononuclear cells and polymorphonuclear leukocytes in the subepithelium $(3 / 10)$ as well as some evidence of glandular hypertrophy (4/10). The upper airway specimens demonstrated morphology consistent with normal nasal epithelial mucosa.

Table 2. - Patient information and expression of the inducible isoform of cyclo-oxygenase (COX-2)

\begin{tabular}{|c|c|c|c|c|c|c|c|c|c|c|}
\hline \multirow[t]{2}{*}{$\begin{array}{l}\text { Patient } \\
\text { No. }\end{array}$} & \multirow[t]{2}{*}{$\begin{array}{l}\text { Age } \\
\text { yrs }\end{array}$} & \multirow[t]{2}{*}{ Sex } & \multirow[t]{2}{*}{ Diagnosis } & \multirow[t]{2}{*}{ Atopic } & \multirow[t]{2}{*}{ Asthma } & \multirow[t]{2}{*}{$\begin{array}{l}\text { FEV1 } \\
\% \text { pred }\end{array}$} & \multirow[t]{2}{*}{$\begin{array}{l}\text { Last } \\
\text { smoked }\end{array}$} & \multirow[t]{2}{*}{ Medications } & \multicolumn{2}{|c|}{$\begin{array}{c}\text { Epithelial COX-2 } \\
\text { expression }\end{array}$} \\
\hline & & & & & & & & & ISH & $\mathrm{IHC}$ \\
\hline 1 & 55 & $\mathrm{M}$ & Squamous cell carcinoma & $\mathrm{N}$ & $\mathrm{N}$ & 88 & 2 weeks & Nil & 3.1 & 2.1 \\
\hline 2 & 40 & $\mathrm{~F}$ & Bronchoalveolar carcinoma & Y & $\mathrm{N}$ & 96 & Never & Nil & 2.1 & 1.0 \\
\hline 3 & 75 & $\mathrm{M}$ & Squamous cell carcinoma & $\mathrm{N}$ & $\mathrm{N}$ & 89 & 1 month & $\begin{array}{l}\text { Ranitidine, } \\
\text { indomethacin }\end{array}$ & 2.7 & 1.1 \\
\hline 4 & 64 & $\mathrm{~F}$ & Metastatic breast carcinoma & $\mathrm{N}$ & $\mathrm{N}$ & 93 & $8 \mathrm{yrs}$ & Tamoxifen & 0 & 0 \\
\hline 5 & 73 & $\mathrm{~F}$ & Adenocarcinoma & $\mathrm{N}$ & $\mathrm{N}$ & 98 & 5 yrs & $\begin{array}{l}\text { Metoprolol, } \\
\text { aspirin }\end{array}$ & 3.4 & 1.2 \\
\hline 6 & 54 & $\mathrm{~F}$ & Large cell carcinoma & $\mathrm{N}$ & $\mathrm{N}$ & 105 & $10 \mathrm{yrs}$ & Oestrogen & 2.1 & 1.9 \\
\hline 7 & 60 & M & Atypical carcinoid & $\mathrm{N}$ & $\mathrm{N}$ & 88 & $27 \mathrm{yrs}$ & Nil & 1.4 & 1.9 \\
\hline 8 & 51 & $\mathrm{~F}$ & Adenocarcinoma & $\mathrm{N}$ & $\mathrm{Y}$ & 88 & 2 weeks & $\begin{array}{l}\text { Salbutamol MDI, } \\
\text { budesonide MDI }\end{array}$ & 1.2 & 3.7 \\
\hline 9 & 69 & $\mathrm{M}$ & Squamous cell carcinoma & $\mathrm{N}$ & $\mathrm{N}$ & 68 & $20 \mathrm{yrs}$ & Nil & 2.9 & 2.0 \\
\hline 10 & 64 & M & Large cell carcinoma & $\mathrm{N}$ & Y & 64 & $15 \mathrm{yrs}$ & $\begin{array}{l}\text { Ranitidine, verapamil, } \\
\text { salbutamol MDI, } \\
\text { beclomethasone MDI }\end{array}$ & 4.2 & 4.5 \\
\hline
\end{tabular}

FEV1: forced expiratory volume in one second. M: male; F: female; Y: yes; N: no; MDI: metered-dose inhaler, ISH: in situ hybridization; IHC: immunohistochemistry. 
Table 3. - Patient information and expression of the inducible isoform of cyclooxygenase (COX-2) in upper airway sections

\begin{tabular}{|c|c|c|c|c|c|c|c|c|c|}
\hline \multirow{2}{*}{$\begin{array}{l}\text { Pt. } \\
\text { No. }\end{array}$} & \multirow{2}{*}{$\begin{array}{l}\text { Age } \\
\text { yrs }\end{array}$} & \multirow[t]{2}{*}{ Sex } & \multirow[t]{2}{*}{ Diagnosis } & \multirow[t]{2}{*}{ Procedure } & \multirow[t]{2}{*}{ Atopic } & \multirow[t]{2}{*}{ Smoker } & \multirow[t]{2}{*}{ Medications } & \multicolumn{2}{|c|}{ Epithelial COX-2 expression } \\
\hline & & & & & & & & ISH & $\mathrm{IHC}$ \\
\hline 1 & 30 & M & $\begin{array}{l}\text { Deviated nasal septum, } \\
\text { chronic sinusitis }\end{array}$ & $\begin{array}{l}\text { Septoplasty, } \\
\text { turbinectomy }\end{array}$ & No & Never & Nasal steroid & 4.2 & 5.6 \\
\hline 2 & 58 & $\mathrm{~F}$ & $\begin{array}{l}\text { Obstructive sleep apnoea, } \\
\text { deviated nasal septum }\end{array}$ & Turbinectomy & No & Yes & Nasal steroid & 3.1 & 5.1 \\
\hline 3 & 34 & M & $\begin{array}{l}\text { Deviated nasal septum, } \\
\text { inferior turbinate } \\
\text { hypertrophy, snoring }\end{array}$ & $\begin{array}{l}\text { Palatoplasty, } \\
\text { turbinectomy }\end{array}$ & No & Never & Nil & 2.0 & 3.8 \\
\hline 4 & 47 & $\mathrm{~F}$ & Deviated nasal septum & $\begin{array}{l}\text { Septoplasty, } \\
\text { turbinectomy }\end{array}$ & No & Ex & Nil & 3.4 & 4.5 \\
\hline 5 & 44 & M & $\begin{array}{l}\text { Deviated nasal septum, } \\
\text { nasal obstruction }\end{array}$ & Turbinectomy & No & Ex & Salbutamol MDI & 2.1 & 2.9 \\
\hline
\end{tabular}

Pt.: patient. For definitions see footnote to table 2.

\section{COX-2 expression in airway specimens}

The presence of COX-2 mRNA was examined in ten lower airway and five nasal turbinate specimens by in situ hybridization. The hybridization signal using a COX-2 antisense RNA probe was focal, non-uniform and localized to the pseudostratified columnar epithelium and subepithelial layer. A specific hybridization signal was observed in 9/10 lower airway specimens and $5 / 5$ upper airway specimens. In the lower airway sections, both medium- and small-sized airways demonstrated a similar hybridization pattern. This consisted of a focal perinuclear hybridization signal surrounding individual columnar epithelial cells. Airway resident epithelial cells also demonstrated a focal perinuclear hybridization signal, which was observed adjacent to areas of epithelial hybridization. A scattered lowlevel hybridization signal was observed in airway cartilage and smooth muscle, however, this did not appear to be significantly above background signal intensity. Bronchusassociated lymphoid tissue (BALT) also demonstrated specific hybridization which was localized to lymphoid cells. Control specimens hybridized with a complementary sense RNA probe were negative. Representative sections are shown in figures $1-3$.

COX-2 protein immunolocalization studies confirmed the in situ hybridization findings, with a strong association between in situ hybridization and immunohistochemical staining seen in adjacent sections. In lower airway sections, focal cytoplasmic immunostaining was observed in columnar epithelial cells in close association with subepithelial staining in the airway-resident inflammatory cells. In addition to focal cytoplasmic staining, more extensive and intense apical staining was observed at the luminal surface of the airway epithelium, involving the cilial layer and the cytoplasmic layer immediately below. This pattern was more prominent in the upper airway specimens. Airwayresident inflammatory cells demonstrated focal cytoplasmic staining. This was seen predominantly in mononuclear cells, however, occasional cytoplasmic staining in polymorphonuclear granulocytes was also detected. More focal cytoplasmic immunostaining of BALT lymphocytes was observed, which was less extensive than the in situ hybridization findings. Specimens incubated with the COX-2 antibody pre-adsorbed with purified COX-2 protein show- ed marked reduction or ablation of immunoperoxidase staining. These findings are summarised in figures $1-3$. No association was observed between the histological changes in airway structure referred to above and $\mathrm{COX}-2$ expression. Semiquantitative analysis of COX-2 expression in airway epithelial cells is shown in table 2.

\section{COX-2 expression in cultured human airway epithelium}

Both BEAS-2B and A549 cells grown in standard conditions were examined for COX-2 mRNA and protein expression. COX-2 mRNA expression was detected by RT-PCR/Southern blot analysis in both cell lines, as demonstrated by a 728 base pair (bp) PCR amplification product which hybridized with a COX-2-specific probe on Southern blot analysis. Identical results were seen in BEAS-2B cells cultured without growth factors for $24 \mathrm{~h}$ and in A549 cells grown serum-free from 24 or $48 \mathrm{~h}$ (data not shown). COX-2 mRNA was not detectable by Northern blot analysis of $20 \mu \mathrm{g}$ of total cellular RNA in either cell type under standard culture conditions. When the cells were stimulated with a combination of interferon (IFN)$\gamma\left(100 \mathrm{U} \cdot \mathrm{mL}^{-1}\right)$, tumour necrosis factor (TNF)- $\alpha(500$ $\mathrm{U} \cdot \mathrm{mL}^{-1}$ and interleukin (IL)-1 $\beta\left(5 \mathrm{U} \cdot \mathrm{mL}^{-1}\right)$ (BoehringerMannheim, Castle Hill, NSW, Australia) for $6 \mathrm{~h}$, upregulation of COX-2 mRNA expression was seen in A549 cells by Northern blot analysis but not in BEAS-2B cells. The results of these experiments are presented in figure 4 .

COX-2 protein expression was examined by Western immunoblotting of cell protein extracts in cells cultured under standard conditions. In both BEAS-2B and A549 cells, COX-2 protein was detected as demonstrated by an immunoblot signal at $\sim 72 \mathrm{kDa}$. COX-2 detected in cell protein extracts was slightly larger than the band obtained by immunoblot analysis of purified COX-2 protein. These data are shown in figure 4.

\section{Discussion}

Widespread expression of COX-2 has been demonstrated in the epithelium of human airways without clinical or histological evidence of overt airway inflammation. This supports recent findings of so-called "quasiconstitutive" COX-2 expression in the epithelium of normal 

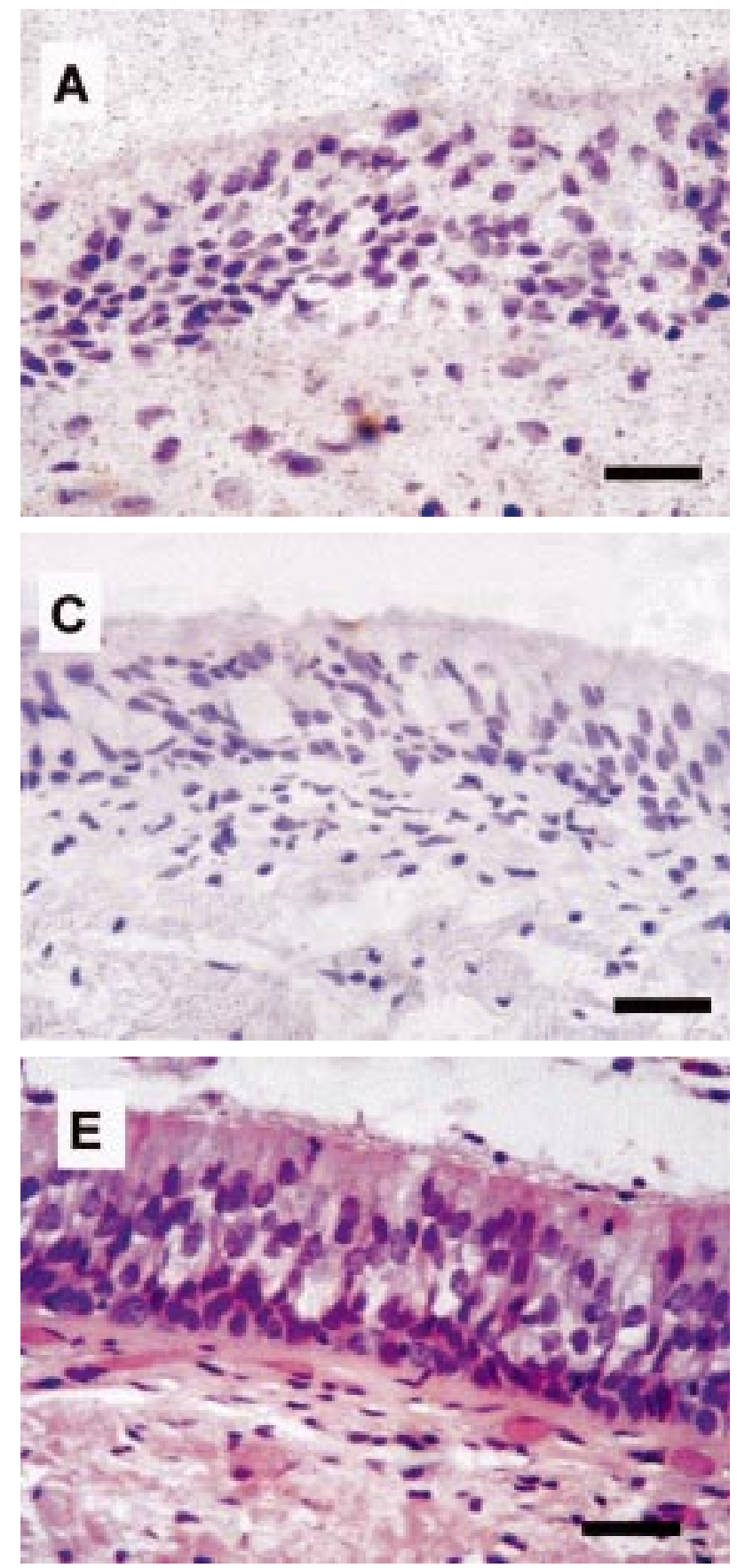

subjects studied at bronchoscopy [17]. Similar "constitutive" expression of COX-2 in nasal respiratory epithelium has recently been reported by immunohistochemical analysis of sinoscopic biopsy specimens [18]. Although this airway epithelial COX-2 expression may reflect exposure to cigarette smoke, viral infection or airborne allergens, which may chronically upregulate regional cytokine production, this would seem a less likely explanation for the present findings. In particular, all but two of the lower airway subjects had ceased smoking some years prior to surgery. However, as the airway epithelium is regarded as the first line of defence against inhaled pathogens and irritants [19], induction of COX-2
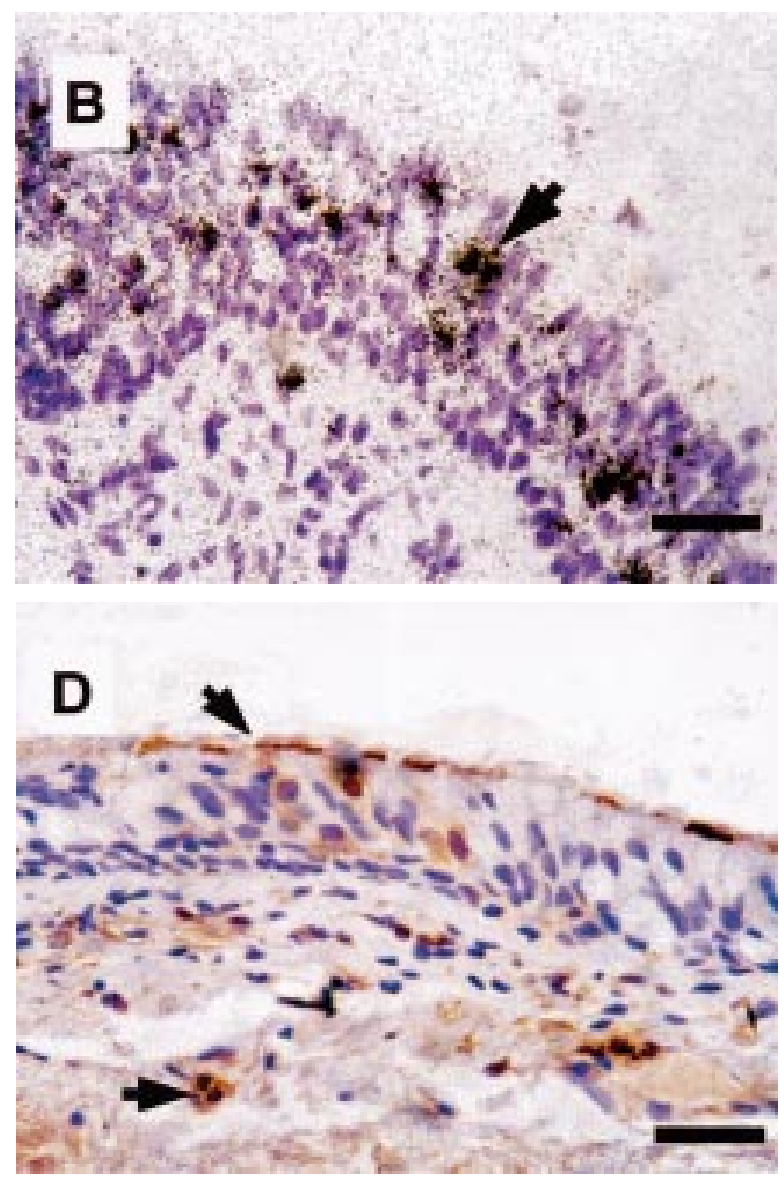

Fig. 1. - Localization of the inducible isoform of cyclo-oxygenase (COX2) in serial sections obtained from a lower human airway specimen. A) In situ hybridization study using a COX-2 sense ribonucleic acid (RNA) probe. B) In situ hybridization using a COX-2 antisense RNA probe, demonstrating a focal perinuclear hybridization signal in columnar epithelial cells (arrow). C) Immunohistochemical study using a COX-2specific polyclonal antibody incubated with an equimolar concentration of purified COX-2 protein. D) Immunohistochemical study using a COX-2-specific polyclonal antibody, demonstrating extensive staining at the luminal surface of columnar epithelial cells (upper arrow), focal cytoplasmic staining in columnar epithelial cells and cytoplasmic staining in airway-resident inflammatory cells (lower arrow). E) Haematoxylin and eosin-stained section (Internal scale bars $=7.5 \mu \mathrm{m}$.)

may represent an early response to low level environmental inflammatory stimuli, and as such may not be distinguishable from "constitutive" expression.

In contrast to these findings, SousA et al. [20] demonstrated diffuse cytoplasmic COX-2 staining in bronchial biopsies from asthmatics, which was significantly increased when compared with normal airway biopsies. The different cellular localization demonstrated in the present study may reflect the differing COX-2 antibodies and immunohistochemical methologies used, crush artefact induced by bronchoscopic biopsy or an altered COX-2 cellular localization profile in asthmatic subjects. In opposition to this is the finding of similar COX-2 

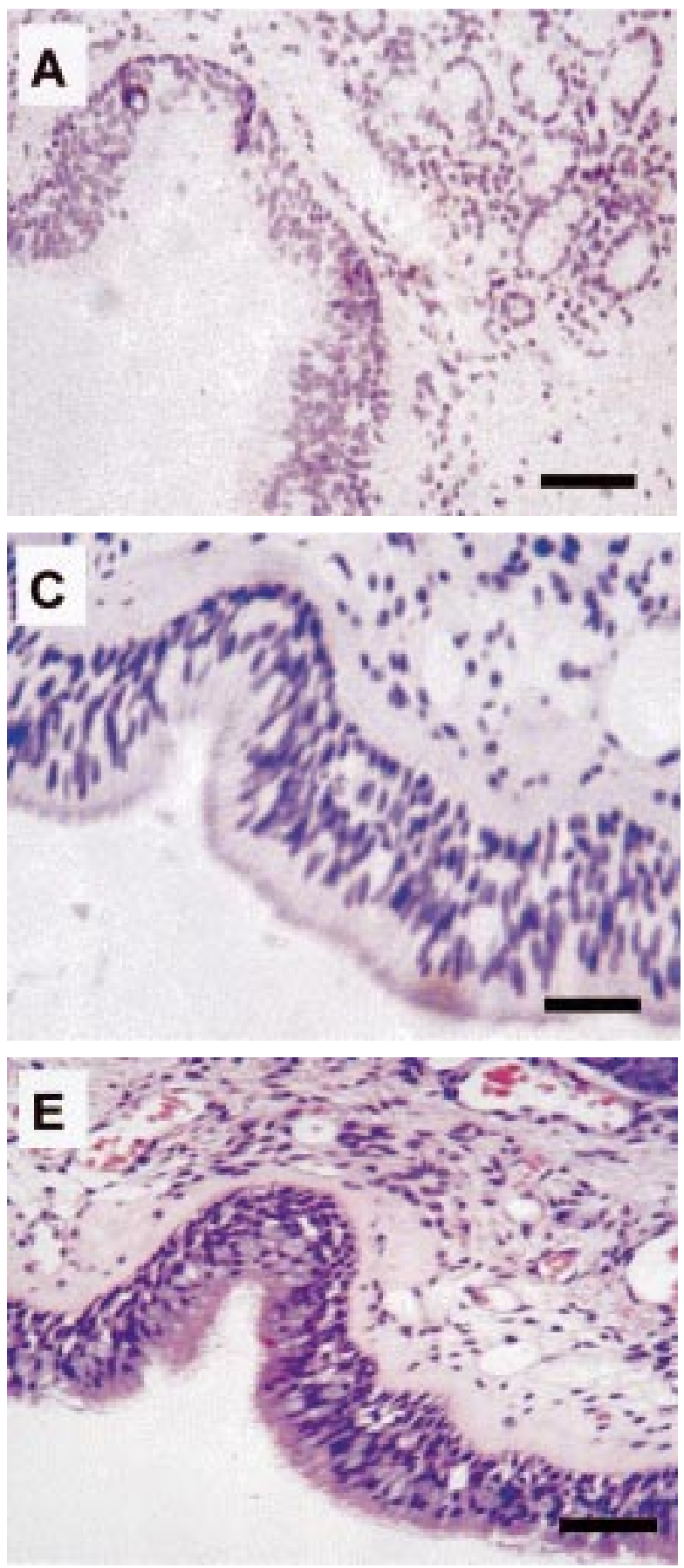

expression in two asthmatic airways compared with the remainder of the lower airway samples.

Immunohistochemical localization of COX-2 in the respiratory epithelium in this study demonstrated distinct polarization to the apical region of columnar epithelial cells. Using a different COX-2 antibody, Demoly et al. [17] demonstrated diffuse cytoplasmic staining COX-2 in bronchial biopsy tissue without distinct apical distribution. Although this discrepancy may reflect differences in antibody specificity, this would seem unlikely based on the ablation of staining by adsorption with purified COX2 protein seen in the present study, and the similarity
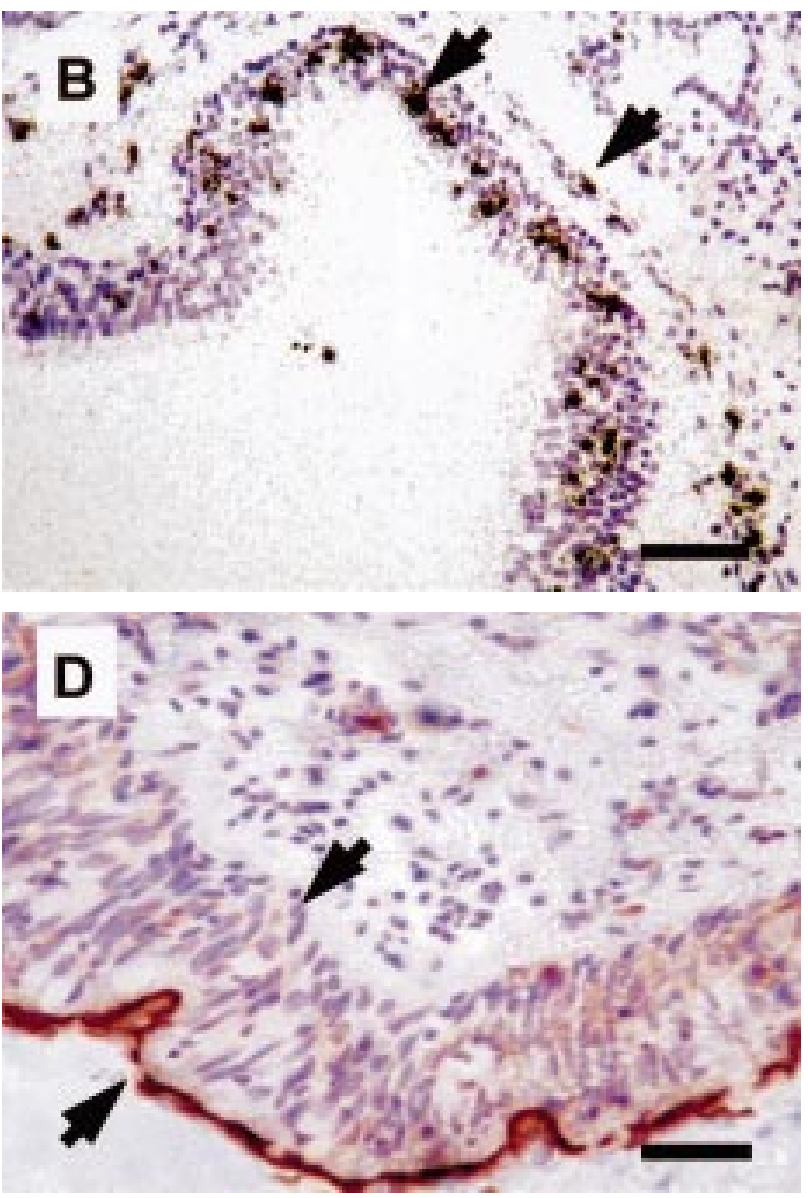

Fig. 2. - Localization of the inducible isoform of cyclo-oxygenase (COX2 ) in serial sections obtained from an upper human airway specimen. A) In situ hybridization study using a COX-2 sense ribonucleic acid (RNA) probe. B) In situ hybridization using a COX-2 antisense RNA probe, demonstrating a focal perinuclear hybridization signal in columnar epithelial cells (upper arrow) and airway-resident inflammatory cells (lower arrow). C) Immunohistochemical study using a COX-2-specific polyclonal antibody incubated with an equimolar concentration of purified COX-2 protein. D) Immunohistochemical study using a COX-2-specific polyclonal antibody, demonstrating intense staining at the luminal surface of columnar epithelial cells (upper arrow) and diffuse cytoplasmic staining in columnar epithelial cells limited by the basement membrane (lower arrow). E) Haematoxylin and eosin-stained section (Internal scale bars $\mathrm{A}$ and $\mathrm{B}=15 \mu \mathrm{m} ; \mathrm{C}-\mathrm{E}=7.5 \mu \mathrm{m}$.)

between these findings and those of IsEKI [12] who demonstrated distinct apical polarization of COX-2 immunostaining in rat gastric epithelium. Although preliminary studies of COX-2 subcellular localization have suggested binding to the nuclear membrane [5], extensive cell fraction studies have not been performed in epithelial cells.

Studies of primary human airway epithelial cell cultures have demonstrated that COX-2 is the constitutive and dominant isoform, and that COX-2 expression and activity in these cells is not dependent on the presence of peptide growth factors $[21,22]$. Although these studies provide 

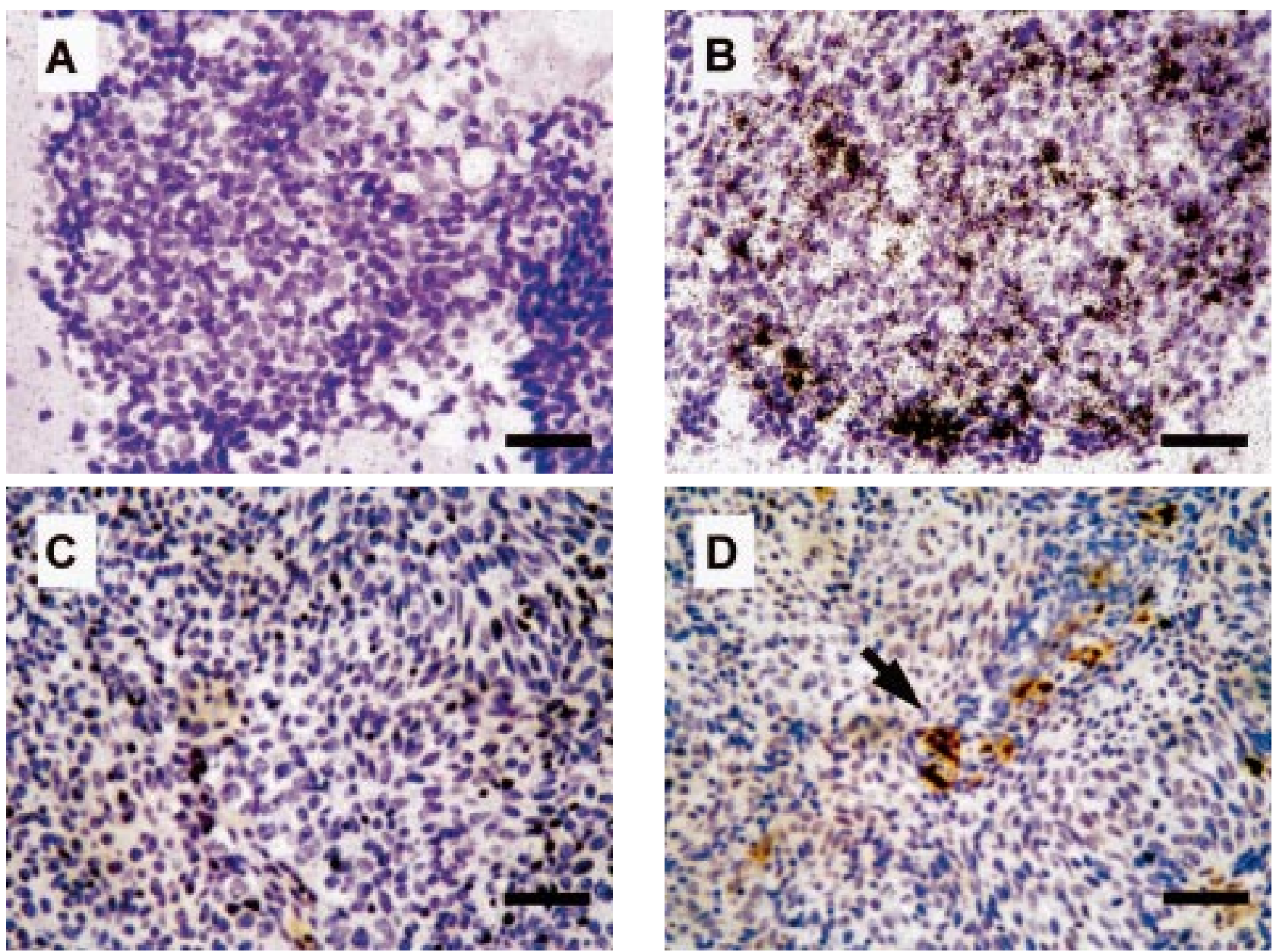

Fig. 3. - Localization of the inducible isoform of cyclo-oxygenase (COX-2) in bronchus-associated lymphoid tissue. A) In situ hybridization study using a COX-2 sense ribonucleic acid (RNA) probe. B) In situ hybridization using a COX-2 antisense RNA probe, demonstrating focal perinuclear hybridization signal in lymphoid cells. C) Immunohistochemical study using a COX-2-specific polyclonal antibody incubated with an equimolar concentration of purified COX-2 protein. D) Immunohistochemical study using a COX-2-specific polyclonal antibody, demonstrating cytoplasmic staining of lymphoid cells (arrow). (Internal scale bars=7.5 $\mu \mathrm{m}$.)

support for constitutive expression of COX-2 in human airway epithelium in vivo, it is likely that different mechanisms may be involved in the expression of COX-2 in this study's cell culture models. In particular A549 cells are a malignant cell line, and may possess autocrine cytokine pathways which are well characterized in many human cancers [23]. In addition, oncogenic ras mutations, including those present in A549 cells, are associated with activation of both the phospholipase $\mathrm{A}_{2}$ and COX-2 pathways [24].

In contrast both to these findings and those of other studies [8, 25], Akarasereenont and Thiemermann [26] did not demonstrate constitutive COX-2 expression in A549 cells. One possible explanation for this discrepancy is the differing cell culture, immunoblot and $\mathrm{PGE}_{2}$ assay methodologies employed in this study. Although the transcriptional regulation of COX-2 in cultured human airway epithelium may differ from that seen in vivo, the expression and activity of COX-2 in these cell lines makes them a useful model for the study of COX-2 biology in the human airway.

The presence of COX-2 mRNA in unstimulated A549 cells detected by RT-PCR but not by Northern blot analysis in the present study suggests that low levels of the transcript and resultant protein may be insufficient to result in significant $\mathrm{PGE}_{2}$ production. This contention is further supported by the findings of cytokine upregulation of COX-2 mRNA in A549 cells detected by Northern blot analysis. Alternatively, cytokine-induced activation of the phospholipase pathway may result in an increased supply of arachidonic acid to the "constitutively" expressed COX-2.

Prostanoid production associated with activation of the COX-2 pathway is dependent on the presence of a cellspecific prostaglandin synthase $[1,5]$. Although differential expression of these enzymes has not been studied in airway cells, a large number of in vitro studies suggest that COX-2 expression in human airway epithelium is associated with $\mathrm{PGE}_{2}$ production [4, 8, 27], resident mononuclear cells with $\mathrm{PGE}_{2}$ and $\mathrm{PGF}_{2 \alpha}$ production and airway smooth muscle with $\mathrm{PGF}_{2 \alpha}$ release [1]. Although recent in vitro studies have demonstrated cytokine-mediated COX-2 induction in cultured human airway smooth muscle cells $[28,29]$, the present study did not demonstrate evidence of COX-2 localization in airway smooth muscle in vivo. In view of the opposing effects of these prostanoids on smooth muscle contractility and airway 
a)

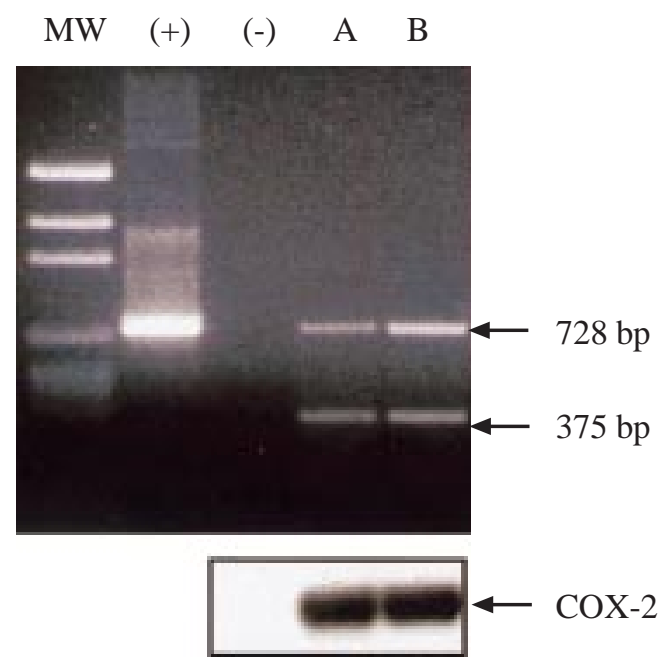

b)

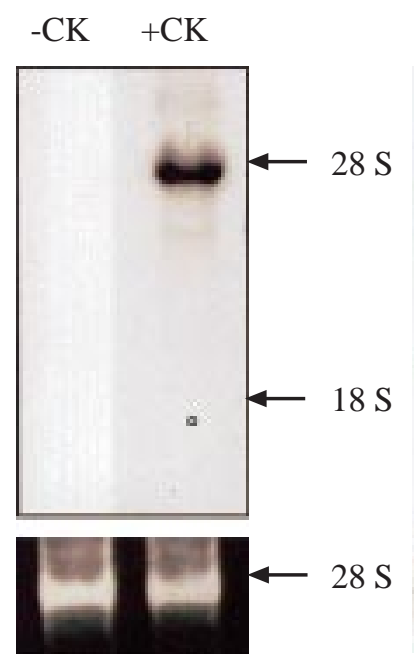

c)

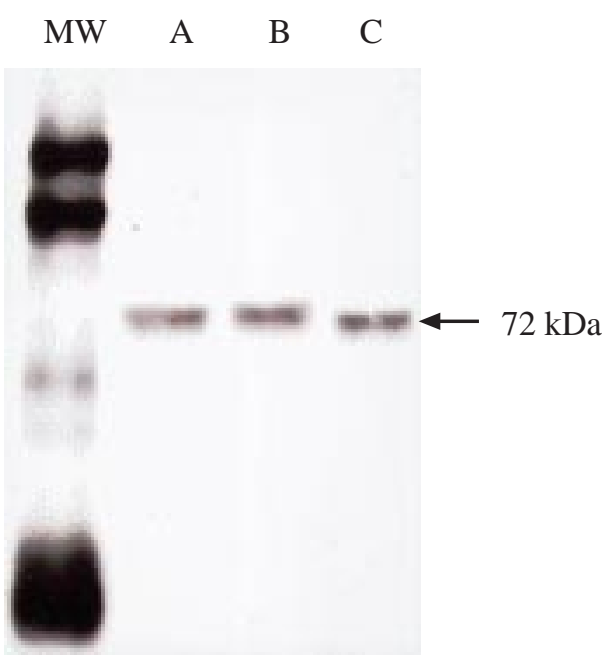

Fig. 4. - Expression of the inducible isoform of cyclo-oxygenase (COX-2) in cultured human airway epithelial cells. a) Detection of COX-2 messenger ribonucleic acid (mRNA) in human airway epithelial cells cultured under standard conditions by reverse transcription-polymerase chain reaction/ Southern blot analysis. Gel electrophoresis (upper panel) demonstrated an amplification product at 728 base pair (bp) $(\mathrm{COX}-2)$ and 375 bp $(\beta$-actin). $(+)$ : positive control; (-): negative control. Southern blot analysis using a COX-2-specific probe (lower panel) demonstrating specific hybridization to the 728 bp band. b) Detection of COX-2 mRNA in A549 cells by Northern blot analysis. A band just below the $28 \mathrm{~S}$ RNA is visible after hybridization with a COX-2-specific probe in the cytokine-treated (+CK) but not control (-CK) cells. The ethidium bromide-stained $28 \mathrm{~S}$ RNA is shown to demonstrate equal lane loading. c) Detection of COX-2 protein in human airway epithelial cells cultured under standard conditions by Western blot analysis. MW: molecular weight markers; A: A549 cells; B: BEAS-2B cells; C: purified COX-2 protein.

inflammatory responses, the factors determining the dominant prostaglandin in the human airway may be important in the development of diseases such as asthma.

The finding of focal COX-2 expression in BALT in this study suggests that prostanoids may be important regulators of the immune response in the human airway. The results clearly demonstrate the cellular origin of the $\mathrm{PGE}_{2}-$ production associated with lymph node efferents [30], and to the author's knowledge is the first study to demonstrate COX-2 expression in lymph node tissue. As prostaglandins have important regulatory effects on the cellular immune system [31], the presence of COX-2 in human airway lymphoid tissue suggests a potentially important role for prostanoid metabolites in the regulation of the human mucosal immune system. Moreover, recent findings that $\mathrm{PGE}_{2}$ may direct naive $\mathrm{CD} 4+\mathrm{T}$ cells toward a T-helper (Th) 2 phenotype [32] and differentiation of murine B-lymphocytes towards IgE-secreting cells [33] directly implicate airway COX-2 expression and prostanoid production in the pathophysiology of airway inflammatory disease such as asthma. Characterization of the lymphoid cell phenotypes associated with COX-2 induction will be required to further delineate the role of $\mathrm{PGE}_{2}$ in the regulation of the cellular immune system.

The presence of widespread activation of COX-2 in the airway epithelium and resident inflammatory cells of the upper and lower human airway strongly implicates products of the prostanoid pathway in the regulation of human airway function. These findings have implications for the homeostatic role of epithelial-derived prostaglandin $\mathrm{E}_{2}$, as well as the regulation of airway inflammation and smooth muscle tone in inflammatory airway disease. Further evaluation of airway prostanoid regulation in both animal models and clinical studies is required to define the importance of COX-2 expression in the upper and lower airway.
Acknowledgements: The authors would like to thank the cardiothoracic surgeons and pathologists of Sir Charles Gairdner Hospital for their assistance.

\section{References}

1. Sigal E. The molecular biology of mammalian arachidonic acid metabolism. Am J Physiol 1991; 260: L13L28.

2. Pavord ID, Tattersfield AE. Bronchoprotective role for endogenous prostaglandin $E_{2}$. Lancet 1995; 345: 436438.

3. Knight DA, Stewart GA, Thompson PJ. Histamine tachyphylaxis in human airway smooth muscle - the role of $\mathrm{H}_{2}$ receptors and the epithelium. Am Rev Respir Dis 1992; 146: 137-140.

4. Watkins DN, Garlepp MJ, Thompson PJ. Regulation of the inducible cyclooxygenase pathway in cultured human airway epithelial cells by nitric oxide. $\mathrm{Br} J$ Pharmacol 1997; 12: 1482-1488.

5. Otto JC, Smith WL. Prostaglandin endoperoxide synthases 1 and 2. J Lipid Mediat Cell Signal 1995; 12: 139-156.

6. DeWitt D, Smith WL. Yes, but do they still get headaches? Cell 1995; 83: 345-348.

7. Goppelt-Stuebe M. Regulation of prostaglandin endoperoxide synthase (cyclooxygenase) isozyme expression. Prostaglandins Leukot Essent Fatty Acids 1995; 52: 213-222.

8. Mitchell JA, Belvisi MG, Akarasereenont P, et al. Induction of cyclooxygenase 2 by cytokines in human pulmonary epithelial cells: regulation by dexamethasone. Br J Pharmacol 1994; 1113: 1008-1014.

9. Vigano T, Habib A, Hernandez A, et al. Cyclooxygenase2 and synthesis of $\mathrm{PGE}_{2}$ in human bronchial smooth muscle cells. Am J Respir Crit Care Med 1997; 155: 864-868.

10. Morham SG, Langenbach R, Loftin CD, et al. Prostaglandin synthase 2 gene disruption causes severe renal pathology in the mouse. Cell 1995; 83: 473-482. 
11. Reuter BK, Asfaha S, Buret A, Sharkey KA, Wallace JL. Exacerbation of inflammation associated colonic injury in rat through inhibition of cyclooxygenase 2. J Clin Invest 1996; 98: 2076-2085.

12. Iseki S. Immunocytochemical localisation of cyclooxygenase 1 and cyclooxygenase 2 in the rat stomach. Histochem $J$ 1995; 27: 323-328.

13. Lechner JF, LaVeck MA. A serum-free method for culturing normal human bronchial epithelial cells at clonal density. J Tissue Culture Meth 1985; 9: 43-48.

14. Watkins DN, Peroni DJ, Basclain KA, Garlepp MJ, Thompson PJ. Expression and activity of nitric oxide synthases in human airway epithelium. Am J Respir Cell Mol Biol 1997; 16: 629-639.

15. Leiber M. A continuous tumour cell line from human lung carcinoma with properties of type II alveolar epithelial cells. Int J Cancer 1976; 17: 62-70.

16. Detre S, Saccani Jotti G, Dowsett M. A quickscore method for immunohistochemical semiquantitation: validation for oestrogen receptor in breast carcinomas. $J$ Clin Pathol 1995; 48: 876-878.

17. Demoly P, Jaffuel D, Lequeux N, et al. Prostaglandin H synthase 1 and 2 immunoreactivities in the bronchial mucosa of asthmatics. Am J Respir Crit Care Med 1997; 155: 670-675.

18. Demoly P, Crampette L, Lebel B, Campbell AM, Mondain M, Bousquet J. Expression of cyclooxygenases 1 and 2 proteins in upper respiratory mucosa. Clin Exp Allergy 1998; 28: 278-283.

19. Thompson AB, Robbins RA, Romberger DJ, Spurzem JR, Teschler H, Rennard SI. Immunological functions of the pulmonary epithelium. Eur Respir J 1995; 8: 127149.

20. Sousa AR, Pfister R, Christie PE, et al. Enhanced expression of cyclo-oxygnease isoenzyme $2(\mathrm{COX}-2)$ in asthmatic airways, and its cellular distribution in aspirin sensitive asthmatics. Thorax 1997; 52: 940-945.

21. Asano K, Lilly CM, Drazen JM. Prostaglandin G/H synthase-2 is the constitutive and dominant isoform in cultured human lung epithelial cells. Am J Physiol 1996; 271: L126-L131.

22. Walenga RW, Kester M, Coroneos E, Butcher S, Dwivedi $\mathrm{R}$, Statt C. Constitutive expression of prostaglandin endoperoxide G/H synthase (PGHS-2) but not PGHS-1 in human tracheal epithelial cells in vitro. Prostaglandins 1996; 52: 341-359.
23. Mizuno K, Sone S, Orino E, Nii A, Ogura T. Autonomous expression of cytokine genes by human lung cancer cells and their paracrine regulation. Jap J Cancer Res 1994; 85: 179-186.

24. Heasley LE, Thaler S, Nicks M, Price B, Skorecki K, Nemenoff RA. Induction of cytosolic phopsholipase $\mathrm{A}_{2}$ by oncogenic ras in human non small cell lung cancer. $J$ Biol Chem 1997; 272: 14501-14504.

25. Newton R, Kuitert LME, Berbmann M, Adcock IM, Barnes PJ. Evidence for involvement of NF- $\mathrm{KB}$ in the transcriptional control of COX-2 gene expression by IL13. Biochem Biophys Res Comm 1997; 237: 28-32.

26. Akarasereenont $\mathrm{P}$, Thiemermann $\mathrm{C}$. The induction of cyclo-oxygenase- 2 in human pulmonary epithelial cell culture (A549) activated by IL-lbeta is inhibited by tyrosine kinase inhibitors. Biochem Biophys Res Commun 1996; 220: 181-185.

27. Holtzman MJ. Arachidonic acid metabolism in airway epithelial cells. Ann Rev Physiol 1992; 54: 303-329.

28. Belvisi MG, Saunders MA, Haddad el-B, et al. Induction of cyclooxygenase 2 by cytokines in human cultured airway smooth muscle cells: novel inflammatory role for this cell type. Br J Pharmacol 1997; 120: 910-916.

29. Pang LK, Knox AJ. Effect of interleukin-1 beta, tumour necrosis factor alpha and interferon gamma on the induction of cyclooxygenase 2 in cultured human airway smooth muscle cells. Br J Pharmacol 1997; 121: 579587.

30. Moore TC, Spruck CH, Lami JL, Said SI. Prompt elevations of $\mathrm{PGE}_{2}$ and thromboxane $\mathrm{A}_{2}$ metabolites in peripheral node efferent lymph of sheep following drainage area immunization. Immunopharmacology 1989; 17: 380.

31. Della Bella S, Molteni M, Compasso S, Zulian C, Vanoli M, Scorza R. Differential effects of cyclooxygenase pathway metabolites on cytokine production by lymphocytes. Prostaglandins Leukot Essent Fatty Acids 1997; 56: 177184.

32. Katamura K, Shintaku N, Yamauchi Y, et al. Prostaglandin $\mathrm{E}_{2}$ at priming of naive CD4 $+\mathrm{T}$ cells inhibits acquisition and ability to produce IFN-gamma and IL-2, but not IL-4 and IL-5. J Immunol 1995; 155: 4604-4612.

33. Fedyk ER, Phipps RP. Prostaglandin $E_{2}$ receptors of the $\mathrm{EP}_{2}$ and $\mathrm{EP}_{4}$ subtypes regulate activation and differentiation of mouse B lymphocytes to IgE secreting cells. Proc Natl Acad Sci USA 1996; 93: 10978-10983. 